\title{
The polymorphism rs3024505 proximal to IL-10 is associated with risk of ulcerative colitis and Crohns disease in a Danish case-control study
}

\author{
Vibeke Andersen*1, Anja Ernst3, Jane Christensen², Mette Østergaard1,8, Bent A Jacobsen4, Anne Tjønneland², \\ Henrik B Krarup ${ }^{3}$ and Ulla Voge $\left.\right|^{5,6,7}$
}

\begin{abstract}
Background: Crohns disease (CD) and ulcerative colitis (UC) are characterized by a dysregulated inflammatory response to normal constituents of the intestinal flora in the genetically predisposed host. Heme oxygenase-1 (HO-1/ HMOX1) is a powerful anti-inflammatory and anti-oxidant enzyme, whereas the pro-inflammatory interleukin $1 \beta(I L-1 \beta /$ ILIB) and anti-inflammatory interleukin 10 (IL-10/IL 10) are key modulators for the initiation and maintenance of inflammation. We investigated whether single nucleotide polymorphisms (SNPS) in the IL-1 $\beta, I L-10$, and HO-1 genes, together with smoking, were associated with risk of $C D$ and $U C$.

Methods: Allele frequencies of the IL-13T-31C (rs1143627), and IL-10 rs3024505, G-1082A (rs1800896), C-819T (rs1800871), and C-592A (rs1800872) and HO-1 A-413T (rs2071746) SNPs were assessed using a case-control design in a Danish cohort of 336 CD and 498 UC patients and 779 healthy controls. Odds ratio (OR) and 95\% confidence interval $(95 \% \mathrm{Cl})$ were estimated by logistic regression models.

Results: Carriers of rs3024505, a marker polymorphism flanking the $I L-10$ gene, were at increased risk of CD (OR $=1.40$, $95 \% \mathrm{Cl}: 1.06-1.85, \mathrm{P}=0.02)$ and $\mathrm{UC}(\mathrm{OR}=1.43,95 \% \mathrm{Cl}: 1.12-1.82, \mathrm{P}=0.004)$ and, furthermore, with risk of a diagnosis of $C D$ and $U C$ at young age $(O R=1.47,95 \% \mathrm{Cl}: 1.10-1.96)$ and $O R=1.35,95 \% \mathrm{Cl}: 1.04-1.76)$, respectively). No association was found between the IL-1 1 , IL-10 G-1082A, C-819T, C-592A, and HO-1 gene polymorphisms and CD or UC. No consistent interactions between smoking status and CD or UC genotypes were demonstrated.

Conclusions: The rs3024505 marker polymorphism flanking the IL-10 gene was significantly associated with risk of UC and $C D$, whereas no association was found between $I L-1 \beta$ or $H O-1$ gene polymorphisms and risk of $C D$ and $U C$ in this Danish study, suggesting that $I L-10$, but not $I L-1 \beta$ or $H O-1$, has a role in IBD etiology in this population.
\end{abstract}

\section{Background}

The chronic inflammatory bowel diseases (IBD), ulcerative colitis (UC) and Crohn's disease (CD), are complex diseases caused by an interplay between genetic and environmental factors [1].

The recent years have brought much progress regarding the genetics in IBD and the number of confirmed IBD associated loci and genes have risen dramatically [2-7]. Yet, still, only part of the genetic contribution to disease risk may be explained by the identified genes $[8,9]$.

\footnotetext{
* Correspondence: va9791@gmail.com

${ }^{1}$ Medical Department, Viborg Regional Hospital, DK-8800 Viborg, Denmark Full list of author information is available at the end of the article
}

Northern European populations, including the Danish, generally have low frequencies of the CD risk-associated variants of CARD15 [3,10], and it is therefore of interest to search for more genetic determinants in these populations. Less progress has been achieved in the identification of environmental risk factors and geneenvironmental interactions. Differences in environmental exposures and genetic heterogeneity between ethnic groups may have complicated the search for genetic and gene-environmental determinants.

The emerging picture of IBD pathogenesis is focused on the sequential occurrence of pivotal events leading to the initiation and subsequent perpetuation of inflamma- 
tion $[11,12]$. First, the initial interaction between luminal constituents and intestinal epithelial cells leads to activation of the innate immune system [11]. The recognition of highly conserved pathogen structures such as lipopolysaccharide (LPS), the main constituent of Gram-negative bacteria, by Toll-like receptors and other pattern recognition receptors on the epithelial and other immunologically active cells in the intestine, initiates the release of various cytokines and enzymes, including interleukins (IL) and heme oxygenase-1 [13,14]. Second, the inflammation will eventually become chronic due to defective regulation of the immune response. Therefore, polymorphisms in genes encoding cytokines and other molecules involved in the innate immune system, may affect the course of the inflammatory cascade and thereby the risk of developing IBD.

Activation of the pro-inflammatory IL- $1 \beta$ leads to production of prostaglandin $\mathrm{E}_{2}\left(\mathrm{PGE}_{2}\right)$ and nitric oxide $(\mathrm{NO})$ via the induction of cyclo-oxygenase 2 (COX-2) and inducible nitric oxide synthase (iNOS) among others [15]. $I L-1 \beta$ knock-out mice have no spontaneous abnormalities, however, on challenge with LPS, a less pronounced acute phase response is observed, suggesting that IL-1 $\beta$ is required for an adequate immune response [15]. In both CD and UC patients, high levels of IL-1 $\beta$ are found in the intestinal mucosa [16] and stimulation by IL-1 $\beta$ leads to a more pronounced inflammatory response in CD immune cells compared to cells from healthy controls [17]. The variant alleles of two $I L-1 \beta$ promoter polymorphisms, $I L$ $1 \beta \mathrm{T}-31 \mathrm{C}$ and $I L-1 \beta \mathrm{C}-511 \mathrm{~T}$, have been found to be in almost complete linkage disequilibrium [18], and the haplotypes encompassing the $I L-1 \beta \mathrm{T}-31 \mathrm{C}$ variant conferred higher transcription of $I L-1 \beta$ compared to the wild type haplotype [18]. The role of $I L-1 \beta$ polymorphisms in IBD has been explored in several studies [19-24]. These studies did not find any association with $I L-1 \beta$, however, the studies were rather small.

IL-10 is an anti-inflammatory cytokine, which leads to dampening of the activated immune system. $I L-10$ knockout mice develop colitis if they are not kept in germ-free environment [25], and the administration of IL-10 ameliorates the inflammation in animal and in vitro models [26]. In patients, an impaired IL-10 production has been fund in severe cases of CD and UC $[27,28]$. Recently, a strong association between the marker rs3024505 immediately downstream of the IL-10 gene and adult UC was found in a genome-wide association study [29]. This study also found a modest association between this marker and CD risk [29]. However, no association was found for rs3024493, a linked polymorphism located in an intron in the $I L-10$ gene, in a case-control study of paediatric onset CD [30]. The $I L-10$ promoter is polymorphic and genetic variation may account for different levels of cytokine production [31]. The $I L-10$ promotor polymorphisms G-1082A, C-819T, and C-592A have been most extensively studied. They are in tight linkage disequilibrium [32] and the haplotype encompassing these three polymorphisms is associated with low IL-10 protein production in lymphocytes in vitro [32] and low of levels of circulating IL-10 protein in Kenyan children [33] probably because the A allele of the $I L-10$ promoter polymorphism C-592A leads to the formation of a binding site for the ETS family of transcription factors [34]. Studies on the $I L-10$ promoter polymorphisms and IBD susceptibility have been inconsistent [22,29-31,35-40].

Heme oxygenase-1 (HO-1) is involved in the degradation of heme, thereby reducing oxidative stress and protecting against acute and chronic inflammation [41]. Animal models of IBD have confirmed the anti-inflammatory effect of HO-1 [42]. Hence, blockade of HO-1 activity results in exacerbation of experimental colitis whereas increased HO-1 pathway activity ameliorates experimental murine colitis [43-45]. Carbon monoxide (CO) is one of the main metabolite of the HO-1 pathway and $\mathrm{CO}$ administration has been shown to ameliorate chronic colitis in IL-10 deficient mice [42,46]. In UC patients, HO-1 expression and protein levels have been reported to be increased in inflamed colon compared to normal mucosa from patients with UC [47]. Studies using luciferase reporter assays of a functional promoter polymorphism, HO-1 A-413T, indicated that the A allele promoter had significantly higher activity than the $\mathrm{T}$ allele promoter [48]. The AA genotype of this polymorphism has been associated with a reduced incidence of ischemic heart disease [48]. Another promoter polymorphism, the HO-1 (GT)N dinucleotide repeat polymorphism, was not associated with risk of inflammatory bowel disease [49]. Interestingly, smoking affects the risk of IBD differentially, increasing the risk of $\mathrm{CD}$ and reducing the risk of UC [50]. The mechanisms by which smoking affects risk of IBD is not clear and as tobacco smoke contains more than 3000 chemicals, several different mechanisms may be involved. Nicotine has been reported to modulate the immune balance in a Th1-dominant direction [51] in accordance with the beneficial effect of smoking on UC. Moreover, smoking increases the production of certain pro-inflammatory cytokines, but, on the other hand, smoking is a source of carbon monoxide (CO). Thus, another possible mechanisms may involve interactions between smoking and IL-1 $\beta$, IL-10 and HO-1 activity in relation to intestinal inflammation [46].

In this study we wanted to assess the role of polymorphisms in $I L-1 \beta, I L-10$, and $H O-1$ together with smoking in relation to risk of developing IBD in a Danish casecontrol study of $336 \mathrm{CD}, 498 \mathrm{UC}$ and 779 healthy controls, respectively. 


\section{Methods}

\section{Patients and controls}

Patients with CD $(\mathrm{n}=373)$ or UC $(\mathrm{n}=541)$, and healthy controls $(\mathrm{n}=796)$ were included. All information was available for $336 \mathrm{CD}$ cases, $498 \mathrm{UC}$ cases and 779 healthy controls. Diagnosis of CD or UC was based on clinical, radiological, endoscopic and histological examinations [52]. Infectious and other cases of inflammatory bowel diseases were excluded. IBD diagnoses were classified on basis of disease localization according to the Montreal classification; L1, L2, and L3 signifies ileal, colonic, and ileocolonic localisation in CD and E1, E2, and E3 signifies the extent of colon involvement in UC; proctitis (inflammation limited to rectum), left side (inflammation distal to the left flexure), and extensive colon (inflammation proximal to the left flexure) [53]. Patients were recruited from Viborg, Aalborg and Herning Regional Hospitals from January 2004 to March 2005. Healthy blood donors were recruited from Viborg Hospital. Subjects under the age of 18 and with ethnicity other than Caucasian were excluded from the study. Phenotypic data on age at diagnosis of disease, localisation, family disposition for IBD, and medical and surgical treatment of disease was collected. Information on smoking habits at the time of diagnosis (patients) and smoking habits at study entry (donors) was collected.

\section{Genotyping}

DNA was extracted from EDTA-stabilized peripheral blood samples from all patients and healthy controls by using either a PureGene (Gentra Systems, Minneapolis, MN, USA) or Wizard Genomic (Promega, Madison, WI, USA) DNA purification kit, according to the manufacturers' recommendations.

SNPs were chosen from literature studies. $I L-1 \beta \mathrm{T}-31 \mathrm{C}$ (rs1143627), and $I L-10$ C-592T (rs1800872) were genotyped as previously described [54] Rs3024505, IL-10 G1082A (rs1800896), C-819T (rs1800871) [29] were genotyped using the pre-developed allelic discrimination assays C_15983681 20, C_1747360_10 and C_1747362_10 (Applied Biosystems). The genotyping reaction was performed in a final volume of $6 \mu \mathrm{l}$ consisting of $3 \mu \mathrm{l}$ Universal PCR Master Mix, $0.075 \mu \mathrm{l} 40 \times$ assay-on-demand mix, $1.925 \mu \mathrm{H}_{2} \mathrm{O}$, and $1 \mu \mathrm{l}$ genomic DNA. HO-1 A-413T (rs2071746 was determined using the pre-developed allelic discrimination assay C_15869717_10 (Applied Biosystems). Genotyping was performed by TaqMan real-time PCR on an ABI7900HT (Applied Biosystems), using Allelic Discrimination. Twenty ng of DNA was genotyped in $5 \mu \mathrm{l}$ containing $1 \times$ Mastermix (Applied Biosystems, Nærum, Denmark), 100 $\mathrm{nM}$ probes, and $900 \mathrm{nM}$ primers or as recommended by the manufacturer for predesigned assays.. Controls of known genotypes were included in each run, and repeated genotyping of a random $10 \%$ subset yielded $100 \%$ identical genotypes. Laboratory personnel were blinded to the case/control status of the study group [55].

\section{Statistical analyses}

We used logistic regression to analyse the relationship between the six polymorphisms and disease. The statistical analyses included only subjects where all information was available. Age was entered linear in the model after checking for linearity using a linear spline [56]. Subgroup analyses were done for the polymorphisms in relation to location of the disease (CD: L1, L2, L3, UC: E1, E2, E3), and age at diagnosis (above or not above 40 years of age) for the cases. The GENMOD procedure in SAS release 9.1 (SAS Institute, Inc., Cary, North Carolina, USA) was used for the statistical analyses.

\section{Power analyses}

We used Genetic Power Calculator for Case - control for discrete traits [57] for power analyses. This study has more than $80 \%$ power to detect a dominant effect with an OR of 1.5 in either CD or in UC or 1.4 if CD and UC were combined.

\section{Ethical Considerations}

All subjects received written and oral information and gave written informed consent. The study was conducted in accordance with the Declaration of Helsinki and approved by the local Scientific Ethical Committees at Viborg and Aalborg County (VN 2003/5).

\section{Results}

Characteristics of the Danish IBD patients and controls are shown in Table 1. A total of 834 Danish patients and 779 controls were included. $51 \%$ of the CD patients were current smokers at the time of diagnosis, whereas only $17 \%$ of the UC patients were current smokers. The genotype distributions among the controls did not deviate from Hardy-Weinberg equilibrium. The variant allele frequencies for $I L-1 \beta \mathrm{T}-31 \mathrm{C}, I L-10$ rs3024505, G-1082A, C819T, C-592A and HO-1 A-413T were 0.35, 0.18, 0.45, $0.21,0.21$, and 0.42 , respectively, in the control group.

\section{Associations between polymorphisms and disease}

Carriers of the variant allele of rs3024505 flanking the $I L$ 10 gene were at increased risk of both $\mathrm{CD}$ and UC. Homozygous variant allele carriers were at 2.48 -fold (95\% CI: 1.27-4.84) increased risk of CD and heterozygous carriers were at 1.31-fold (95\% CI: 0.98-1.75) increased risk of $\mathrm{CD}$ after adjusting for age, gender and smoking status (Table 2). Homozygous variant allele carriers were at 2.31-fold (95\% CI: 1.27-4.20) increased risk of UC and heterozygous carriers were at 1.34-fold (95\% CI: $1.04-$ 1.73) increased risk of $\mathrm{UC}$ after adjusting for age, gender and smoking status (Table 3). After correction for multi- 
Table 1: The basic descriptions of the Danish study subjects'

\begin{tabular}{|c|c|c|c|}
\hline & $\begin{array}{c}\text { Crohns Disease } \\
\quad(n=336)\end{array}$ & $\begin{array}{l}\text { Ulcerative Colitis } \\
\qquad(n=498)\end{array}$ & $\begin{array}{l}\text { Controls } \\
(n=779)\end{array}$ \\
\hline \multicolumn{4}{|l|}{ Gender: $\mathrm{n}(\%)$} \\
\hline male & $131(39)$ & $241(48)$ & $397(51)$ \\
\hline female & $205(61)$ & $257(52)$ & $382(49)$ \\
\hline \multicolumn{4}{|l|}{ Age: } \\
\hline Median (5\%-95\%) & $43(23-77)$ & $49(24-76)$ & $43(23-60)$ \\
\hline \multicolumn{4}{|l|}{ Age at diagnosis: } \\
\hline Median (5\%-95\%) & $30(15-65)$ & $35(17-68)$ & \\
\hline \multicolumn{4}{|l|}{ Smoking habits: $\mathrm{n}(\%)$} \\
\hline Smokers & $170(51)$ & $85(17)$ & $204(26)$ \\
\hline Never smokers & $120(36)$ & $231(46)$ & $391(50)$ \\
\hline Former smokers & $46(14)$ & $182(37)$ & $184(24)$ \\
\hline \multicolumn{4}{|l|}{ Location UC2: } \\
\hline Proctitis (E1) & & $211(42)$ & \\
\hline Left side (E2) & & $183(37)$ & \\
\hline Extensive (E3) & & $94(19)$ & \\
\hline Data not available & & $10(2)$ & \\
\hline \multicolumn{4}{|l|}{ Location CD²: n (\%) } \\
\hline Colonic (L2) & $75(22)$ & & \\
\hline Ileal (L1) & $155(46)$ & & \\
\hline Ileocolonic (L3) & $93(28)$ & & \\
\hline Data not available & $13(4)$ & & \\
\hline \multicolumn{4}{|l|}{ Medication: $\mathrm{n}(\%)$} \\
\hline Advanced $^{3}$ & $142(42)$ & $104(21)$ & \\
\hline $\begin{array}{l}\text { No advanced } \\
\text { medication }{ }^{4}\end{array}$ & $189(56)$ & $390(78)$ & \\
\hline Data not available & $5(1)$ & $4(1)$ & \\
\hline \multicolumn{4}{|l|}{ Operation: n (\%) } \\
\hline Yes & $153(46)$ & $15(3)$ & \\
\hline No & $176(52)$ & $473(95)$ & \\
\hline Data not available & $7(2)$ & $10(2)$ & \\
\hline
\end{tabular}

${ }^{1}$ The analyses included subjects where all information was available,

${ }^{2}$ The location of $C D$ and $U C$ in accordance with the Montreal classification are shown

3azathioprin, 6-mercaptopyrine, Tumor Necrosis Factor-inhibitors, or methrotrexate,

45-aminosalicylic acid, prednisolone

ple testing the associations were borderline statistically significant. Minor allele frequencies of $I L-10$ gene polymorphisms in selected studies are shown in Table 4.

No association was found between the $I L-1 \beta, I L-10 \mathrm{G}$ 1082A, C-819T, C-592A, and HO-1 polymorphisms and risk of $\mathrm{CD}$ or UC (Table 2 and 3 ). The three $I L-10$ promoter polymorphisms were found to be in almost complete linkage as previously described for Caucasians [32]. Therefore, no haplotype analyses were performed.
No significant difference in the genotype distribution between $\mathrm{CD}$ and $\mathrm{UC}$ was found (data not shown). When combining $\mathrm{UC}$ and $\mathrm{CD}$ data to increase the statistical power there were still no associations between the $I L-1 \beta$, the three $I L-10$ promoter polymorphisms, and $H O-1$ gene polymorphisms and risk of IBD (results not shown).

Subgroup analyses showed that variant allele carriers of rs3024505 were at 1.47 -fold (95\% CI: $1.10-1.96)$ and 1.35 fold (95\% CI: 1.04-1.76) higher risk of a diagnosis of CD 
Table 2: Genotypes in Danish patients with Crohns Disease1.

\begin{tabular}{|c|c|c|c|c|c|c|c|c|c|}
\hline IL1 $\beta$ C-31T & \multirow[t]{2}{*}{$\mathbf{N}_{\text {case }}$} & \multirow{2}{*}{$\mathbf{N}_{\text {control }}$} & \multicolumn{2}{|c|}{ OR $(95 \% \mathrm{Cl})^{2}$} & \multicolumn{2}{|c|}{ OR $(95 \% \mathrm{Cl})^{3}$} & \multicolumn{2}{|c|}{ OR $(95 \% \mathrm{Cl})^{4}$} & P-value $^{5}$ \\
\hline (rs1143627) & & & & & & & & & \\
\hline$\pi$ & 165 & 342 & 1.00 & - & 1.00 & - & 1.00 & - & \\
\hline CT & 139 & 342 & 0.84 & $(0.64-0.10)$ & 0.85 & $(0.65-1.12)$ & 0.86 & $(0.65-1.14)$ & 0.29 \\
\hline CC & 32 & 95 & 0.70 & $(0.45-1.09)$ & 0.71 & $(0.45-1.10)$ & 0.69 & $(0.44-1.09)$ & 0.11 \\
\hline $\mathrm{CT}$ and $\mathrm{CC}$ & 171 & 437 & 0.81 & $(0.63-1.05)$ & 0.82 & $(0.63-1.07)$ & 0.82 & $(0.63-1.07)$ & 0.15 \\
\hline \multicolumn{10}{|l|}{$\begin{array}{l}\text { IL-10 C-592A } \\
\text { (rs1800872) }\end{array}$} \\
\hline $\mathrm{CC}$ & 214 & 483 & 1.00 & - & 1.00 & - & 1.00 & - & \\
\hline$A C$ & 114 & 261 & 0.99 & $(0.75-1.29)$ & 0.98 & $(0.75-1.30)$ & 1.01 & $(0.76-1.34)$ & 0.97 \\
\hline $\mathrm{AA}$ & 8 & 35 & 0.52 & $(0.24-1.13)$ & 0.53 & $(0.24-1.16)$ & 0.54 & $(0.24-1.21)$ & 0.13 \\
\hline$A C$ and $A A$ & 122 & 296 & 0.93 & $(0.71-1.21)$ & 0.93 & $(0.71-1.22)$ & 0.95 & $(0.72-1.25)$ & 0.72 \\
\hline \multicolumn{10}{|l|}{$\begin{array}{l}\text { IL-10 C-819T } \\
\text { (rs1800871) }\end{array}$} \\
\hline CC & 216 & 483 & 1.00 & - & 1.00 & - & 1.00 & - & \\
\hline CT & 111 & 259 & 0.96 & $(0.73-1.26)$ & 0.95 & $(0.72-1.25)$ & 0.97 & $(0.73-1.29)$ & 0.83 \\
\hline$\pi$ & 9 & 37 & 0.54 & $(0.26-1.15)$ & 0.55 & $(0.26-1.18)$ & 0.56 & $(0.26-1.22)$ & 0.14 \\
\hline $\mathrm{CT}$ and $\mathrm{TT}$ & 120 & 296 & 0.91 & $(0.69-1.18)$ & 0.90 & $(0.69-1.18)$ & 0.92 & $(0.70-1.21)$ & 0.55 \\
\hline \multicolumn{10}{|l|}{$\begin{array}{l}\text { IL-10 G-1082A } \\
\text { (rs1800896) }\end{array}$} \\
\hline GG & 109 & 238 & 1.00 & - & 1.00 & - & 1.00 & - & \\
\hline AG & 171 & 374 & 1.00 & $(0.75-1.33)$ & 0.99 & $(0.74-1.33)$ & 0.97 & $(0.72-1.32)$ & 0.87 \\
\hline$A A$ & 56 & 167 & 0.73 & $(0.50-1.07)$ & 0.75 & $(0.51-1.10)$ & 0.78 & $(0.53-1.16)$ & 0.23 \\
\hline$A G$ and $A A$ & 227 & 541 & 0.92 & $(0.70-1.21)$ & 0.92 & $(0.69-1.21)$ & 0.92 & $(0.69-1.22)$ & 0.56 \\
\hline \multicolumn{10}{|l|}{ (rs3024505) } \\
\hline $\mathrm{CC}$ & 203 & 522 & 1.00 & - & 1.00 & - & 1.00 & - & \\
\hline $\mathrm{CT}$ & 114 & 235 & 1.25 & $(0.95-1.64)$ & 1.27 & $(0.96-1.68)$ & 1.31 & $(0.98-1.75)$ & 0.07 \\
\hline$\pi$ & 19 & 22 & 2.22 & $(1.18-4.19)$ & 2.60 & $(1.36-4.96)$ & 2.48 & $(1.27-4.84)$ & 0.01 \\
\hline $\mathrm{CT}$ and $\mathrm{TT}$ & 133 & 779 & 1.33 & $(1.02-1.73)$ & 1.37 & $(1.05-1.80)$ & 1.40 & $(1.06-1.85)$ & 0.02 \\
\hline \multicolumn{10}{|l|}{$\begin{array}{l}\text { HO-1 A-413T } \\
\text { (rs2071746) }\end{array}$} \\
\hline $\mathrm{AA}$ & 110 & 267 & 1.00 & - & 1.00 & - & 1.00 & - & \\
\hline AT & 165 & 373 & 1.07 & $(0.81-1.43)$ & 1.06 & $(0.79-1.42)$ & 1.05 & $(0.78-1.42)$ & 0.75 \\
\hline$\pi$ & 61 & 139 & 1.07 & $(0.73-1.55)$ & 1.11 & $(0.76-1.62)$ & 1.04 & $(0.70-1.53)$ & 0.86 \\
\hline AT and TT & 226 & 512 & 1.07 & $(0.82-1.41)$ & 1.08 & $(0.82-1.42)$ & 1.05 & $(0.79-1.39)$ & 0.75 \\
\hline
\end{tabular}

${ }^{1} \mathrm{OR}=$ Odds Ratio, $95 \% \mathrm{Cl}=95 \%$ confidence interval,

${ }^{2}$ Crude,

${ }^{3}$ Adjusted for age and gender

${ }^{4}$ Adjusted for age, gender and smoking status.

${ }^{5} \mathrm{P}$ for the fully adjusted estimate 
Table 3: Genotypes in Danish patients with ulcerative colitis'.

\begin{tabular}{|c|c|c|c|c|c|c|c|c|c|}
\hline & $\mathbf{N}_{\text {case }}$ & $\mathbf{N}_{\text {control }}$ & OR $(95 \% \mathrm{Cl})^{2}$ & & OR $(95 \% \mathrm{CI})^{3}$ & & OR $(95 \% \mathrm{Cl})^{4}$ & & P-value ${ }^{5}$ \\
\hline \multicolumn{10}{|l|}{$\begin{array}{l}\text { IL1 } \beta \text { C-31T } \\
\text { (rs1143627) }\end{array}$} \\
\hline$\pi$ & 204 & 342 & 1.00 & - & 1.00 & - & 1.00 & - & \\
\hline СT & 238 & 342 & 1.17 & $(0.92-1.48)$ & 1.15 & $(0.90-1.47)$ & 1.15 & $(0.89-1.47)$ & 0.28 \\
\hline $\mathrm{CC}$ & 56 & 95 & 0.99 & $(0.68-1.43)$ & 0.99 & (0.68-1.46) & 1.02 & $(0.69-1.49)$ & 0.94 \\
\hline $\mathrm{CT}$ and $\mathrm{CC}$ & 294 & 437 & 1.13 & $(0.90-1.42)$ & 1.11 & $(0.88-1.41)$ & 1.12 & $(0.88-1.42)$ & 0.35 \\
\hline \multicolumn{10}{|l|}{$\begin{array}{l}\text { IL-10 C-592A } \\
\text { (rs1800872) }\end{array}$} \\
\hline $\mathrm{CC}$ & 328 & 483 & 1.00 & - & 1.00 & - & 1.00 & - & \\
\hline$A C$ & 149 & 261 & 0.84 & $(0.66-1.07)$ & 0.83 & $(0.65-1.07)$ & 0.83 & $(0.64-1.07)$ & 0.14 \\
\hline$A A$ & 21 & 35 & 0.88 & $(0.51-1.55)$ & 0.99 & $(0.56-1.76)$ & 1.00 & $(0.56-1.77)$ & 0.99 \\
\hline$A C$ and $A A$ & 170 & 296 & 0.85 & $(0.67-1.07)$ & 0.85 & (0.67-1.08) & 0.85 & $(0.66-1.08)$ & 0.18 \\
\hline \multicolumn{10}{|l|}{$\begin{array}{l}\text { IL-10 C-819T } \\
\text { (rs1800871) }\end{array}$} \\
\hline CC & 325 & 483 & 1.00 & - & 1.00 & - & 1.00 & - & \\
\hline $\mathrm{CT}$ & 151 & 259 & 0.87 & $(0.68-1.11)$ & 0.86 & $(0.67-1.11)$ & 0.85 & $(0.66-1.10)$ & 0.22 \\
\hline$\pi$ & 22 & 37 & 0.88 & (0.51-1.53) & 1.00 & $(0.57-1.74)$ & 1.00 & $(0.57-1.75)$ & 0.99 \\
\hline $\mathrm{CT}$ and $\mathrm{TT}$ & 173 & 296 & 0.87 & $(0.69-1.10)$ & 0.88 & $(0.69-1.12)$ & 0.87 & $(0.68-1.11)$ & 0.27 \\
\hline \multicolumn{10}{|l|}{$\begin{array}{l}\text { IL-10 G-1082A } \\
\text { (rs1800896) }\end{array}$} \\
\hline GG & 169 & 238 & 1.00 & - & 1.00 & - & 1.00 & - & \\
\hline AG & 239 & 374 & 0.90 & $(0.70-1.16)$ & 0.91 & $(0.70-1.19)$ & 0.93 & $(0.72-1.22)$ & 0.61 \\
\hline$A A$ & 90 & 167 & 0.76 & $(0.55-1.05)$ & 0.78 & $(0.56-1.08)$ & 0.76 & $(0.54-1.06)$ & 0.10 \\
\hline$A G$ and $A A$ & 329 & 541 & 0.86 & $(0.67-1.09)$ & 0.87 & $(0.68-1.12)$ & 0.88 & $(0.68-1.13)$ & 0.31 \\
\hline \multicolumn{10}{|l|}{ (rs3024505) } \\
\hline $\mathrm{CC}$ & 297 & 522 & 1.00 & - & 1.00 & - & 1.00 & - & \\
\hline $\mathrm{CT}$ & 172 & 235 & 1.29 & $(1.01-1.64)$ & 1.35 & $(1.05-1.73)$ & 1.34 & $(1.04-1.73)$ & 0.02 \\
\hline$\pi$ & 29 & 22 & 2.32 & $(1.31-4.11)$ & 2.37 & $(1.31-4.29)$ & 2.31 & $(1.27-4.20)$ & 0.01 \\
\hline $\mathrm{CT}$ and $\mathrm{TT}$ & 201 & 779 & 1.37 & $(1.09-1.74)$ & 1.43 & $(1.13-1.83)$ & 1.43 & $(1.12-1.82)$ & 0.004 \\
\hline \multicolumn{10}{|l|}{$\begin{array}{l}\text { HO-1 A-413T } \\
\text { (rs2071746) }\end{array}$} \\
\hline$A A$ & 162 & 267 & 1.00 & - & 1.00 & - & 1.00 & - & \\
\hline AT & 251 & 373 & 1.11 & $(0.86-1.43)$ & 1.10 & $(0.85-1.42)$ & 1.11 & $(0.85-1.44)$ & 0.45 \\
\hline$\pi$ & 85 & 139 & 1.01 & $(0.72-1.41)$ & 1.00 & $(0.71-1.41)$ & 1.01 & $(0.71-1.42)$ & 0.98 \\
\hline AT and TT & 336 & 512 & 1.08 & $(0.85-1.37)$ & 1.07 & $(0.84-1.37)$ & 1.08 & $(0.84-1.38)$ & 0.55 \\
\hline
\end{tabular}

${ }^{1} \mathrm{OR}=$ Odds Ratio, $95 \% \mathrm{Cl}=95 \%$ confidence interval,

2 Crude,

${ }^{3}$ Adjusted for age and gender,

${ }^{4}$ Adjusted for age, gender and smoking status.

${ }^{5} \mathrm{P}$ for the fully adjusted estimate 
Table 4: Odds ratios and 95\% confidence intervals (OR ( $\mathrm{CI})$ ) for associations between IL-10 gene polymorphisms and ulcerative colitis (UC) or Crohns disease (CD) in selected case-control studies ${ }^{3}$.

\begin{tabular}{|c|c|c|c|c|c|c|c|}
\hline $\mathrm{N}_{\text {cases/control }}$ & Trs3024505C 1 & Grs3024493T 1 & $\begin{array}{l}\mathrm{C}^{-819 T^{2}} \\
\text { (rs1800871) }\end{array}$ & $\begin{array}{l}\text { C-592A } \\
\text { (rs1800872) }\end{array}$ & $\begin{array}{l}\text { G-1082A2 } \\
\text { (rs1800896) }\end{array}$ & Crs2222202T & \\
\hline \multicolumn{8}{|l|}{ UC } \\
\hline $1855 / 3091$ & $1.46(1.31-1.62)$ & & $\mathrm{Neg}$ & Neg & neg & & [29] \\
\hline $203 / 391$ & & & neg & & $1.66(1.30-2.14)$ & & [36] \\
\hline \multicolumn{8}{|l|}{ CD } \\
\hline $1848 / 1804$ & $1.17(1.01-1.34)$ & & & & & & [29] \\
\hline $270 / 336$ & & neg & $0.77(0.58-1.00)$ & & & $1.29(1.01-1.64)$ & [30] \\
\hline $234-6 / 188-231$ & & & & neg & neg & & [35] \\
\hline
\end{tabular}

${ }^{1}$ rs3024505 and rs3024493 are in complete linkage disequilibrium [30]

2/L-10 G-1082A, C-819T, and C-592A are in linkage disequilibrium [32] C-819T, and C-592A are in complete linkage disequilibrium [34]

${ }^{3}$ Negative associations are indicated by "Neg"

and UC, respectively, before the age of 40 years than the homozygous wildtype carriers (results not shown). No associations between rs3024505 genotype and disease localisation, or between $I L-1 \beta$, the three $I L-10$ promoter polymorphisms, and $H O-1$ polymorphisms and age at diagnosis or disease localisation were found.

\section{Gene-smoking interaction analyses}

The effect of smoking habits at diagnosis on the genotype associations was investigated for $\mathrm{CD}$ and $\mathrm{UC}$, respectively (Additional file 1: Interaction between the studied polymorphisms and smoking status in relation to risk of Crohns Disease and Additional file 2: Interaction between the studied polymorphisms and smoking status in relation to risk of ulcerative colitis). No consistent interactions between smoking status and any of the genotypes were found.

\section{Discussion}

The present case-control study showed that the rs3024505 marker polymorphism flanking the $I L-10$ gene was significantly associated with risk of CD and UC, and, furthermore, with risk of a diagnosis of CD and UC at young age. None of the polymorphisms $I L-1 \beta$ T-31C, $I L-$ 10 G-1082A, C-819T, C-592A, or HO-1 A-413T were associated with risk of $\mathrm{CD}, \mathrm{UC}$, or $\mathrm{UC}$ and $\mathrm{CD}$ combined. No consistent interactions between smoking status and genotypes were found.

Our results replicate the findings by Franke et al. [29] (Table 4). In addition, we found that the association was carried by a stronger association in the younger age group. Franke et al found that the variant allele of rs3024505 was associated with increased risk of UC with OR of 1.46 (95\% CI: 1.31-1.62) and with CD with OR of 1.17 (95\% CI: 1.01-1.34). Furthermore, they found no association between the three $I L-10$ promoter polymor- phisms and risk of UC (results regarding CD were not reported). Previous studies were unable to find association between IBD and the $I L-10$ promoter polymorphisms $[22,31,35,39,40]$ whereas other studies have found associations between paediatric onset of CD and $I L-10 \mathrm{C}$ $819 \mathrm{~T}$ wildtype allele [30], Crs2222202T variant allele [30] and between the $I L-10 \mathrm{G}-1082 \mathrm{~A}$ variant allele and risk of UC [58] (Table 4).

The biological significance of rs3024505 in IBD remains unclear [29]. The polymorphism is is located in an intergenic region proximal to the 3 'UTR end of the $I L$ 10 gene. The region has a high potential for containing regulatory sequences, and may thus regulate $I L-10$ gene expression [29]. Furthermore, rs3024505 is in perfect linkage with other polymorphisms located within the $I L$ 10 gene [29]. On the other hand, since no associations were found between risk of $\mathrm{UC}$ or $\mathrm{CD}$ and the $I L-10$ promoter polymorphisms with proven functional effects on the $I L-10$ gene expression, this may suggest either that the rs3024505 has a much stronger regulatory effect on IL-10 levels than the promoter polymorphisms or that the effect of the polymorphism on disease risk is unrelated to IL-10 expression.

IL-1 $\beta$, IL-10 and HO-1 are key players in the homeostasis of the intestinal immune system. Due to their proinflammatory and anti-inflammatory effects they are of significance for the development and maintenance of chronic inflammation. IL-1 $\beta$ has pro-inflammatory effects, whereas IL-10 and HO-1 have anti-inflammatory effects. A substantial number of studies document the roles of the interleukins, including IL-1 $\beta$ and IL-10, and $\mathrm{HO}-1$ in intestinal inflammation in various animal IBD models and in IBD patients [15,25,26,43-47]. Therefore, genetic variations in these genes may cause imbalance in intestinal homeostasis and thereby contribute to chronic 
inflammation. On this background, $I L-1 \beta, I L-10$ and $H O-$ 1 are relevant candidates for IBD susceptibility genes.

Our results are in accordance with previous studies which were unable to find association between IBD and $I L-1 \beta$ T-31C [24], taqI $[19,23]$ or C-511T $[20,21]$. The HO-1 A-413T polymorphism has not previously been studied in relation to IBD, whereas no association was found between IBD and HO-1 (GT)N [49]. However, all these studies were small, the largest studies included 500 participants, and thus with limited statistical power to exclude an association. The polymorphisms analysed in the present study, $I L-1 \beta \mathrm{T}-31 \mathrm{C}$, and HO-1 A-413T have been shown to have biological effect $[18,48,59]$, and the SNPs have previously been associated to risk of various disease entities $[48,60]$.

We found no consistent interactions between the studied polymorphisms and smoking in relation to risk of $C D$ or UC. Although both smoking and nicotine administration lower the exaggerated IL- $1 \beta$ response in IBD patients $[61,62]$, the present study does not indicate that smoking at the time of diagnosis influences IBD risk by pathways involving $I L-1 \beta, I L-10$ or $H O-1$, since the polymorphisms had no effect among present smokers. Cigarette smoke has been reported to act differentially on inflammation in the small and large intestine, thus worsening small intestinal inflammation, but ameliorating colitis [63]. We were not able to perform subgroup analyses to target this question due to limited statistical power.

It is important to stress the strengths and limitations of the study. The present study included 1600 participants and power analyses showed that this study has more than $80 \%$ power to detect a dominant effect with an OR of 1.5 in relation to either $\mathrm{CD}$ or $\mathrm{UC}$ and or 1.4 if $\mathrm{CD}$ and $\mathrm{UC}$ were combined. Moreover, genetic determinants may be stronger among patients with extensive disease and ileal disease $[64,65]$ and disease onset at low age. The effects of the polymorphisms might thus be below the detection level of our study.

\section{Conclusions}

In conclusion, the rs3024505 marker polymorphism flanking the $I L-10$ gene was associated with risk of UC and $C D$ in the present Danish case-cohort study, and, furthermore, with risk of a diagnosis of $\mathrm{CD}$ and $\mathrm{UC}$ at young age. None of the polymorphisms $I L-1 \beta \mathrm{T}-31 \mathrm{C}, I L-10 \mathrm{G}-$ 1082A, C-819T, C-592A, or HO-1 A-413T were associated with risk of $\mathrm{CD}$ or $\mathrm{UC}$. No consistent interactions between smoking status and genotypes were found. The study suggests that $I L-10$, but not $I L-1 \beta$ or $H O-1$, play a role in IBD etiology.

\section{Additional material}

Additional file 1 Interaction between the studied polymorphisms and smoking status in relation to risk of Crohns Disease. Table.
Additional file 2 Interaction between the studied polymorphisms and smoking status in relation to risk of ulcerative colitis. Table.

\section{Abbreviations}

$\mathrm{CD}$ : Crohns disease; $\mathrm{Cl}$ : confidence interval; $\mathrm{CO}$ : carbon monoxide; COX-2: cyclooxygenase 2; $\mathrm{HO}-1$ : heme oxygenase 1; IBD: inflammatory bowel disease; IL-1 $\beta$ : interleukin 1 $\beta$; L-10: interleukin 10; iNOS: inducible nitric oxide synthase; NO: nitric oxide; OR: odds ratio; RQ-PCR: real-time quantitative RT-PCR; SNP: single nucleotide polymorphism; UC: ulcerative colitis; $\mathrm{PGE}_{2}$ : prostaglandin E2

\section{Competing interests}

The authors declare that they have no competing interests.

\section{Authors' contributions}

UV and $A E$ carried out the genotyping. $V A, H K, A E, M \varnothing, B A J$ established the cohort and/or participated in sample preparation and collection. JC and AT performed the statistical analyses. VA and UV conceived the genotyping study, and its design and coordination and wrote the manuscript. All authors read and approved the final manuscript.

\section{Acknowledgements}

Lars Bentzen is thanked for excellent technical assistance. Patients and donors are kindly thanked for participation. We thank Dr. Andre Franke for the suggestion to include rs3024505 in this study. We thank the staff at the Library, Viborg Regional Hospital. The project has been supported by the "Familien Erichsen Mindefond", the Lundbeck Foundation, the Danish Research Council, the Western Danish Research Forum for Health Science, the County of Viborg, the Danish Colitis-Crohn Association, "John M Klein og hustrus mindelegat" and "The A.P. Møller Foundation for the Advancement of Medical Science".

\section{Author Details}

'Medical Department, Viborg Regional Hospital, DK-8800 Viborg, Denmark, 2Institute of Cancer Epidemiology, Danish Cancer Society, DK-2100 Copenhagen, Denmark, ${ }^{3}$ Department of Clinical Biochemistry, Aarhus University Hospital, DK-9100 Aalborg, Denmark, ${ }^{4}$ Department of Medical Gastroenterology, Aarhus University Hospital, DK-9100 Aalborg, Denmark, ${ }^{5}$ National Food Institute, Technical University of Denmark, DK-2860 Søborg, Denmark, ${ }^{6}$ nstitute for Science, Systems and Models, University of Roskilde, DK-4000 Roskilde, Denmark, ${ }^{7}$ National Research Centre for the Working Environment, DK-2100 Copenhagen, Denmark and ${ }^{8}$ Department of Clinical Biochemistry, Viborg Regional Hospital, DK-8800 Viborg, Denmark

Received: 4 October 2009 Accepted: 28 May 2010

Published: 28 May 2010

\section{References}

1. Xavier RJ, Podolsky DK: Unravelling the pathogenesis of inflammatory bowel disease. Nature 2007, 448:427-434.

2. Franke A, Balschun T, Karlsen TH, Hedderich J, May S, Lu T, et al:: Replication of signals from recent studies of Crohn's disease identifies previously unknown disease loci for ulcerative colitis. Nat Genet 2008, 40:713-715.

3. Ernst A, Jacobsen B, Ostergaard M, Okkels H, Andersen V, Dagiliene E, et al: Mutations in CARD15 and smoking confer susceptibility to Crohn's disease in the Danish population. Scand J Gastroenterol 2007, 42:1445-1451

4. A Catalog of Published Genome-Wide Association Studies, Hindorff LA, Junkins HA, Manolio TA: A Catalog of Published Genome-Wide Association Studies. 2008 [http://www.genome.gov/26525384]. Accessed [20Feb2010]

5. Ostergaard M, Ernst A, Labouriau R, Dagiliene E, Krarup HB, Christensen M, et al: Cyclooxygenase-2, multidrug resistance 1, and breast cancer resistance protein gene polymorphisms and inflammatory bowel disease in the Danish population. Scand J Gastroenterol 2009, 44:65-73.

6. Fisher SA, Tremelling M, Anderson CA, Gwilliam R, Bumpstead S, Prescott NJ, et al:: Genetic determinants of ulcerative colitis include the ECM1 locus and five loci implicated in Crohn's disease. Nat Genet 2008, 40:710-712.

7. Barrett JC, Hansoul S, Nicolae DL, Cho JH, Duerr RH, Rioux JD, et al.: Genome-wide association defines more than 30 distinct susceptibility loci for Crohn's disease. Nat Genet 2008, 40:955-962. 
8. Duerr RH: Update on the genetics of inflammatory bowel disease. $J$ Clin Gastroenterol 2003, 37:358-367.

9. Brant SR, Shugart YY: Inflammatory bowel disease gene hunting by linkage analysis: rationale, methodology, and present status of the field. Inflamm Bowel Dis 2004, 10:300-311.

10. Hugot JP, Zaccaria I, Cavanaugh J, Yang H, Vermeire S, Lappalainen M, et al.: Prevalence of CARD15/NOD2 mutations in Caucasian healthy people. Am J Gastroenterol 2007, 102:1259-1267.

11. Baumgart DC, Carding SR: Inflammatory bowel disease: cause and immunobiology. Lancet 2007, 369:1627-1640.

12. Strober W, Fuss I, Mannon P: The fundamental basis of inflammatory bowel disease. J Clin Invest 2007, 117:514-521.

13. Fukata M, Abreu MT: What Are Toll-like Receptors and what Role May They Have in IBD. Inflamm Bowel Dis 2008, 14:S90-S91.

14. Werner T, Haller D: Intestinal epithelial cell signalling and chronic inflammation: From the proteome to specific molecular mechanisms. Mutat Res 2007, 622:42-57.

15. Dinarello CA: Immunological and inflammatory functions of the interleukin-1 family. Annu Rev Immuno/ 2009, 27(519-50):519-550.

16. Guimbaud R, Bertrand V, Chauvelot-Moachon L, Quartier G, Vidon N Giroud JP, et al: Network of inflammatory cytokines and correlation with disease activity in ulcerative colitis. Am J Gastroenterol 1998, 93:2397-2404

17. Kidd M, Gustafsson BI, Drozdov I, Modlin IM: IL1 beta- and LPS-induced serotonin secretion is increased in EC cells derived from Crohn's disease. Neurogastroenterol Motil 2009, 21:439-450.

18. Chen H, Wilkins LM, Aziz N, Cannings C, Wyllie DH, Bingle C, et al: Single nucleotide polymorphisms in the human interleukin-1B gene affect transcription according to haplotype context. Hum Mol Genet 2006, 15:519-529

19. Hacker UT, Bidlingmaier C, Gomolka M, Keller E, Eigler A, Hartmann G, et al:: Inflammatory bowel disease: no association between allele combinations of the interleukin (IL) I beta and IL-I receptor antagonist gene polymorphisms. Eur J Clin Invest 1998, 28:214-219.

20. Corleto VD, Pagnini C, Margagnoni G, Guagnozzi D, Torre MS, Martorelli M, et al:: IL-1 beta- 511 and IL-1RN*2 polymorphisms in inflammatory bowel disease: An Italian population study and meta-analysis of European studies. Dig Liver Dis 2010, 42:179-84.

21. Ferreira AC, Almeida S, Tavares M, Canedo P, Pereira F, Regalo G, et al:: NOD2/CARD15 and TNFA, but not IL1B and IL1RN, are associated with Crohn's disease. Inflamm Bowel Dis 2005, 11:331-339.

22. Balding J, Livingstone WJ, Conroy J, Mynett-Johnson L, Weir DG, Mahmud $\mathrm{N}$, et al:: Inflammatory bowel disease: the role of inflammatory cytokine gene polymorphisms. Mediators Inflamm 2004, 13:181-187.

23. Stokkers $\mathrm{PC}$, van Aken BE, Basoski N, Reitsma PH, Tytgat GN, van Deventer $\mathrm{SJ}$ : Five genetic markers in the interleukin 1 family in relation to inflammatory bowel disease. Gut 1998, 43:33-39.

24. Queiroz DM, Oliveira AG, Saraiva IE, Rocha GA, Rocha AM, das Gracas Pimenta SM, et al:: Immune response and gene polymorphism profiles in Crohn's disease and ulcerative colitis. Inflamm Bowel Dis 2009, 15:353-358

25. Kuhn R, Lohler J, Rennick D, Rajewsky K, Muller W: Interleukin-10deficient mice develop chronic enterocolitis. Cell 1993, 75:263-274.

26. Ishizuka K, Sugimura K, Homma T, Matsuzawa J, Mochizuki T, Kobayashi M, et al: Influence of interleukin-10 on the interleukin-1 receptor antagonist/interleukin-1 beta ratio in the colonic mucosa of ulcerative colitis. Digestion 2001, 63(Suppl 1):22-7-22-27.

27. Correa I, Veny M, Esteller M, Pique JM, Yaque J, Panes J, et al:: Defective IL10 production in severe phenotypes of Crohn's disease. J Leukoc Biol 2009, 85:896-903.

28. Schreiber S, Heinig T, Thiele HG, Raedler A: Immunoregulatory role of interleukin 10 in patients with inflammatory bowel disease. Gastroenterology 1995, 108:1434-1444.

29. Franke A, Balschun T, Karlsen TH, Sventoraityte J, Nikolaus S, Mayr G, et al: Sequence variants in IL10, ARPC2 and multiple other loci contribute to ulcerative colitis susceptibility. Nat Genet 2008, 40:1319-1323.

30. Amre DK, Mack DR, Morgan K, Israel D, Lambrette P, Costea I, et al:: Interleukin 10 (IL-10) gene variants and susceptibility for paediatric onset Crohn's disease. Aliment Pharmacol Ther 2009, 29:1025-1031.

31. Koss K, Satsangi J, Fanning GC, Welsh Kl, Jewell DP: Cytokine (TNF alpha, LT alpha and IL-10) polymorphisms in inflammatory bowel diseases and normal controls: differential effects on production and allele frequencies. Genes Immun 2000, 1:185-190.

32. Turner DM, Williams DM, Sankaran D, Lazarus M, Sinnott PJ, Hutchinson IV: An investigation of polymorphism in the interleukin-10 gene promoter. Eur J Immunogenet 1997, 24:1-8.

33. Ouma C, Davenport GC, Were T, Otieno MF, Hittner JB, Vulule JM, et al. Haplotypes of IL-10 promoter variants are associated with susceptibility to severe malarial anemia and functional changes in IL10 production. Hum Genet 2008, 124:515-524.

34. Shin HD, Winkler C, Stephens JC, Bream J, Young H, Goedert JJ, et al.: Genetic restriction of HIV-1 pathogenesis to AIDS by promoter alleles of IL10. Proc Nat/ Acad Sci USA 2000, 19(97):14467-14472.

35. Fowler EV, Eri R, Hume G, Johnstone S, Pandeya N, Lincoln D, et al:: TNFalpha and IL10 SNPs act together to predict disease behaviour in Crohn's disease. J Med Genet 2005, 42:523-528.

36. Tedde A, Laura PA, Bagnoli S, Congregati C, Milla M, Sorbi S, et al: Interleukin-10 promoter polymorphisms influence susceptibility to ulcerative colitis in a gender-specific manner. Scand J Gastroenterol 2008, 43:712-718

37. Tagore A, Gonsalkorale WM, Pravica V, Hajeer AH, McMahon R, Whorwell PJ, et al: Interleukin-10 (IL-10) genotypes in inflammatory bowel disease. Tissue Antigens 1999, 54:386-390.

38. Fernandez L, Martinez A, Mendoza JL, Urcelay E, Fernandez-Arquero M, Garcia-Paredes J, et al: Interleukin-10 polymorphisms in Spanish patients with IBD. Inflamm Bowel Dis 2005, 11:739-743.

39. Parkes M, Satsangi J, Jewell D: Contribution of the IL-2 and IL-10 genes to inflammatory bowel disease (IBD) susceptibility. Clin Exp Immunol 1998, 113:28-32.

40. Klein W, Tromm A, Griga T, Fricke H, Folwaczny C, Hocke M, et al:: The IL-10 gene is not involved in the predisposition to inflammatory bowel disease. Electrophoresis 2000, 21:3578-3582.

41. Pae HO, Kim EC, Chung HT: Integrative survival response evoked by heme oxygenase- 1 and heme metabolites. J Clin Biochem Nutr 2008, 42:197-203

42. Lee TS, Chau LY: Heme oxygenase-1 mediates the anti-inflammatory effect of interleukin-10 in mice. Nat Med 2002, 8:240-246.

43. Berberat PO, Rahim YI, Yamashita K, Warny MM, Csizmadia E, Robson SC, et al:: Heme oxygenase-1-generated biliverdin ameliorates experimental murine colitis. Inflamm Bowel Dis 2005, 11:350-359.

44. Paul G, Bataille F, Obermeier F, Bock J, Klebl F, Strauch U, et al:: Analysis of intestinal haem-oxygenase-1 (HO-1) in clinical and experimental colitis. Clin Exp Immunol 2005, 140:547-555.

45. Wang WP, Guo X, Koo MW, Wong BC, Lam SK, Ye YN, et al.: Protective role of heme oxygenase-1 on trinitrobenzene sulfonic acid-induced colitis in rats. Am J Physiol Gastrointest Liver Physiol 2001, 281:G586-G594.

46. Hegazi RA, Rao KN, Mayle A, Sepulveda AR, Otterbein LE, Plevy SE: Carbon monoxide ameliorates chronic murine colitis through a heme oxygenase 1-dependent pathway. J Exp Med 2005, 19(202):1703-1713.

47. Takagi T, Naito Y, Mizushima K, Nukigi Y, Okada H, Suzuki T, et al. Increased intestinal expression of heme oxygenase-1 and its localization in patients with ulcerative colitis. J Gastroenterol Hepatol 2008, 23(Suppl 2):S229-S233.

48. Ono K, Goto Y, Takagi S, Baba S, Tago N, Nonogi H, et al:: A promoter variant of the heme oxygenase-1 gene may reduce the incidence of ischemic heart disease in Japanese. Atherosclerosis 2004, 173:315-319.

49. Hausmann M, Paul G, Kellermeier S, Frey I, Scholmerich J, Falk W, et al:: (GT)N dinucleotide repeat polymorphism of haem oxygenase-1 promotor region is not associated with inflammatory bowel disease risk or disease course. Clin Exp Immunol 2008, 153:81-85.

50. Mahid SS, Minor KS, Soto RE, Hornung CA, Galandiuk S: Smoking and inflammatory bowel disease: a meta-analysis. Mayo Clin Proc 2006 81:1462-1471

51. Kikuchi H, Itoh J, Fukuda S: Chronic nicotine stimulation modulates the immune response of mucosal T cells to Th1-dominant pattern via nAChR by upregulation of Th1-specific transcriptional factor. Neurosci Lett 2008, 432:217-221.

52. Podolsky DK: Inflammatory bowel disease. NEngl J Med 2002, 347:417-429.

53. Satsangi J, Silverberg MS, Vermeire S, Colombel JF: The Montreal classification of inflammatory bowel disease: controversies, consensus, and implications. Gut 2006, 55:749-753. 
54. Macarthur M, Sharp L, Hold GL, Little J, El-Omar EM: The role of cytokine gene polymorphisms in colorectal cancer and their interaction with aspirin use in the northeast of Scotland. Cancer Epidemiol Biomarkers Prev 2005, 14:1613-1618.

55. Vogel U, Christensen J, Wallin H, Friis S, Nexo BA, Tjonneland A: Polymorphisms in COX-2, NSAID use and risk of basal cell carcinoma in a prospective study of Danes. Mutat Res 2007, 617:138-146.

56. Greenland S: Dose-response and trend analysis in epidemiology: alternatives to categorical analysis. Epidemiology 1995, 6:356-365

57. Genetic Power Calculator 2009 [http://pngu.mgh.harvard.edu/ purcell/ $\mathrm{gpc} / \mathrm{cc} 2 \mathrm{html}]$

58. Tedde A, Laura PA, Bagnoli S, Congregati C, Milla M, Sorbi S, et al: Interleukin-10 promoter polymorphisms influence susceptibility to ulcerative colitis in a gender-specific manner. Scand J Gastroenterol 2008, 43:712-718.

59. El-Omar EM, Carrington M, Chow WH, McColl KE, Bream JH, Young HA, et al: Interleukin-1 polymorphisms associated with increased risk of gastric cancer. Nature 2000, 404:398-402.

60. Vogel U, Christensen J, Wallin H, Friis S, Nexo BA, Raaschou-Nielsen O, et al: Polymorphisms in genes involved in the inflammatory response and interaction with NSAID use or smoking in relation to lung cancer risk in a prospective study. Mutat Res 2008, 639:89-100.

61. Birrenbach T, Bocker U: Inflammatory bowel disease and smoking: a review of epidemiology, pathophysiology, and therapeutic implications. Inflamm Bowel Dis 2004, 10:848-859.

62. Aldhous MC, Prescott RJ, Roberts S, Samuel K, Waterfall M, Satsangi J: Does nicotine influence cytokine profile and subsequent cell cycling/ apoptotic responses in inflammatory bowel disease? Inflamm Bowel Dis 2008, 14:1469-1482.

63. Karban A, Eliakim R: Effect of smoking on inflammatory bowel disease: Is it disease or organ specific? World J Gastroenterol 2007, 13:2150-2152.

64. Fowler EV, Doecke J, Simms LA, Zhao ZZ, Webb PM, Hayward NK, et al: ATG16L1 T300A shows strong associations with disease subgroups in a large Australian IBD population: further support for significant disease heterogeneity. Am J Gastroenterol 2008, 103:2519-2526.

65. Achkar JP, Dassopoulos T, Silverberg MS, Tuvlin JA, Duerr RH, Brant SR, et al.: Phenotype-stratified genetic linkage study demonstrates that IBD2 is an extensive ulcerative colitis locus. Am J Gastroenterol 2006 , 101:572-580.

\section{Pre-publication history}

The pre-publication history for this paper can be accessed here: http://www.biomedcentral.com/1471-2350/11/82/prepub

doi: 10.1186/1471-2350-11-82

Cite this article as: Andersen et al., The polymorphism rs3024505 proximal to IL-10 is associated with risk of ulcerative colitis and Crohns disease in a Danish case-control study BMC Medical Genetics 2010, 11:82

Submit your next manuscript to BioMed Centra and take full advantage of:

- Convenient online submission

- Thorough peer review

- No space constraints or color figure charges

- Immediate publication on acceptance

- Inclusion in PubMed, CAS, Scopus and Google Scholar

- Research which is freely available for redistribution

Submit your manuscript at www.biomedcentral.com/submit
C Biomed Central 